\title{
Study on the Influence of Health and Wellness Tourists' Pull Motivation on Revisit Intention-- the Moderating Role of the Push Motivation
}

\author{
Tao Ting ${ }^{1, a}$, Lu Changtai ${ }^{1, b^{*}}$, He Linjun ${ }^{1}$, and Zheng Zhiping ${ }^{1}$ \\ ${ }^{1}$ School of Business and Tourism, Sichuan Agricultural University, Dujiangyan 611830, China
}

\begin{abstract}
Health and wellness tourism is a new form of tourism in which people seek to experience a healthy lifestyle through tourism. From the perspective of demand side, this paper discusses the tourism motivation of health and wellness tourists, and based on a new tourism motivation model, studies the influence mechanism of pull motivation on revisit intention. The results showed that :(1) Pull motivation had a significant positive effect on revisit intention; (2) pushing motivation negatively moderates the relationship between pull motivation and revisit intention.
\end{abstract}

\section{Introduction}

As a new form of tourism, health and wellness tourism has become a new hot topic in academic circles. The National Health and Wellness Tourism Demonstration Base Standard (LB/T 051-2016) points out that health and wellness tourism is the sum of all kinds of tourism activities that make people reach a good state of natural harmony in body, mind and spirit through various means such as nourishing the body, nourishing the diet, cultivating the mind and caring for the environment. Domestic and foreign relevant research contents mainly include the study on the distribution and evaluation of health tourism resources ${ }^{[1-2]}$ and the study on the health and wellness tourism industry and its development potential ${ }^{[3-5]}$, mostly starting from the supply side and mainly focusing on qualitative research ${ }^{[6]}$.

Travel motivation is an important mental state that encourages individual or group travel. Dann put forward the push and pull theory, arguing that "pull" refers to the factors that can attract tourists to a specific tourist destination. It emphasizes the benefits of a specific destination and belongs to external factors. "push", which is based on tourists, aims to meet the physiological and psychological needs of tourists and is an internal factor of tourists themselves ${ }^{[7]}$. Studies on tourism motivation at home and abroad mainly include the dimension of tourism motivation ${ }^{[8-11]}$, the type of tourists based on tourism motivation ${ }^{[12-14]}$, and the relationship between tourism motivation and destination image $^{[8]}$, recommendation intention ${ }^{[9]}$ and revisit intention $^{[15-18]}$. However, many studies simply use the push and pull theory to divide tourism motivation into push motivation and pull motivation, and then study the relationship between tourism motivation and other variables, and few involve the field of health and wellness tourism. Some scholars believe that there is only a simple correlation between push and pull motives $^{[19]}$, but Dann believes that push is logically prior to pull and will have an impact on pull ${ }^{[7]}$. Therefore, in the context of health and wellness tourism, the relationship between the push motivation and the pull motivation, and the influence on the intention to revisit, still need to be further discussed, so as to provide a theoretical basis for the market segmentation and marketing of health and wellness tourism destinations and the improvement of revisit rate, and promote the sustainable development of health and wellness tourism industry.

$\mathrm{Xu}$ and Chan believe that in the context of natural tourism, pull motivation will affect tourists' recommendation intention, and push motivation plays a moderating role between pull motivation and recommendation intention ${ }^{[9]}$. Recommendation intention and revisit intention are both part of attitude loyalty, but they are different. The former emphasizes the possibility of tourists recommending a certain tourist destination to others, while the latter is the possibility of tourists themselves going to a certain destination again. The subjects of tourism are different, but in promoting the sustainable development of tourist destinations, the research on the intention to revisit is of great significance. Previous studies have found that tourism motivation can affect revisit intention and is an important predictor of revisit intention ${ }^{[15-18]}$, and it is pointed out that among push and pull motivations, pull motivation significantly affects revisit intention ${ }^{[17]}$. Therefore, this paper proposes the following hypothesis(the hypothesis model is shown in Figure 1):

H1: The pull motivation of health and wellness tourists has a significantly positive influence on revisit intention

a Author: Tao Ting, (E-mail)1601647005@qq.com.

b* Corresponding author: Lu Changtai, (E-mail)lctwjy@163.com 
H2: The push motivation of health and wellness tourists plays a moderating role between pull motivation and revisit intention

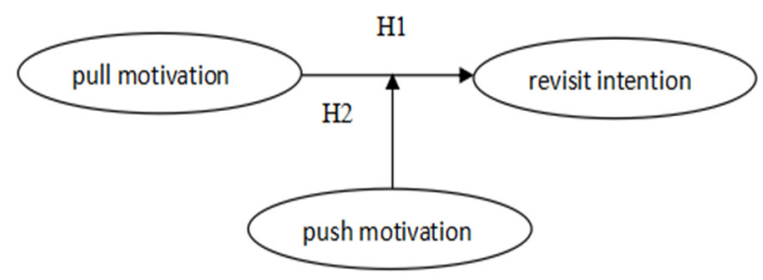

Figure 1. Hypothesis model

\section{Research methods and data collection}

With reference to the tourism motivation related scale ${ }^{[17]}$, a semi-structured interview was conducted on the people who had participated in health and wellness tourism, and the push and pull motivation items of health and wellness tourism were supplemented and improved to meet the research needs, Including 15 push motivation items and 15 pull motivation items. The scale of intention to revisit is based on the studies of Zhao, Luo ${ }^{[16]}$ and Beckman ${ }^{[19]}$, etc., and is modified according to the research needs. It consists of 4 items. The pre-survey was distributed by questionnaire from November 13 to 20, 2020, 110 questionnaires were collected, and 90 questionnaires were collected in Qingcheng Health and Wellness and Recreation Holiday Resort. A total of 200 questionnaires were collected in the preliminary survey. According to the results of the survey, the items were deleted and optimized. The push motivation remained 11 items, and the reliability coefficient was 0.836 .15 items of pull motivation, the reliability coefficient is $0.887 ; 4$ items of revisit intention, and the reliability coefficient is 0.919; A formal questionnaire was formed by adding basic demographic information such as gender, age, education level, occupation and average monthly income. Formal investigation was conducted in the health and wellness tourism resort and health and wellness tourism town of Kunming, Panzhihua and Xichang respectively from November 25 to December 3, 2020. Random sampling survey was conducted on health and wellness tourists. 378 questionnaires were collected, 12 invalid ones were eliminated, and 366 were effectively collected, with an effective recovery rate of about $96.8 \%$.Sample demographic characteristics are shown in Table 1.

Table 1. Demographic characteristics

\begin{tabular}{|c|c|c|c|c|c|c|c|}
\hline category & project & frequency & $\%$ & category & project & frequency & $\%$ \\
\hline \multirow[t]{2}{*}{ Gender } & Male & 136 & 37.2 & Occupation & $\begin{array}{l}\text { Employees of government } \\
\text { agencies or institutions }\end{array}$ & 19 & 5.2 \\
\hline & Female & 230 & 62.8 & & $\begin{array}{l}\text { Enterprise employees or } \\
\text { individual industrial and } \\
\text { commercial households }\end{array}$ & 65 & 17.8 \\
\hline \multirow[t]{5}{*}{ Age } & $\begin{array}{l}20 \text { years old and } \\
\text { below }\end{array}$ & 7 & 1.9 & & Student & 13 & 3.6 \\
\hline & $21-35$ & 80 & 21.9 & & Retirees & 199 & 54.4 \\
\hline & $36-50$ & 53 & 14.5 & & Others & 70 & 19.1 \\
\hline & $51-65$ & 85 & 23.2 & & & & \\
\hline & 65 years old above & 141 & 38.5 & \multirow{2}{*}{$\begin{array}{l}\text { Average } \\
\text { monthly } \\
\text { income }\end{array}$} & $3,000 \mathrm{RMB}$ and below & 82 & 22.4 \\
\hline \multirow{4}{*}{$\begin{array}{l}\text { Education } \\
\text { level }\end{array}$} & $\begin{array}{l}\text { Junior high school } \\
\text { and below }\end{array}$ & 81 & 22.1 & & 3,001-6,000RMB & 196 & 53.6 \\
\hline & $\begin{array}{l}\text { High school or } \\
\text { technical } \\
\text { secondary school }\end{array}$ & 104 & 28.4 & & $6,001-10,000 \mathrm{RMB}$ & 72 & 19.7 \\
\hline & $\begin{array}{l}\text { College or } \\
\text { undergraduate }\end{array}$ & 166 & 45.4 & & More than $10,000 \mathrm{RMB}$ & 16 & 4.4 \\
\hline & $\begin{array}{l}\text { Master's degree } \\
\text { and above }\end{array}$ & 15 & 4.1 & & & & \\
\hline
\end{tabular}

\section{Results and discussion}

\subsection{Reliability and validity analysis}

The reliability test showed that the overall reliability coefficient of the push-pull motivation scale was 0.866 and 0.876 , respectively, and the reliability coefficient of the revisit intention scale was 0.951 , indicating that the reliability of the scale was good. The validity test showed that when the item SFI6 with the cross load greater than 0.4 was deleted, push motivation $\mathrm{KMO}=0.844, \chi^{2}=1761.113, \mathrm{df}=55$, Sig. $=0.000$; pull motivation $\mathrm{KMO}=0.897, \chi^{2}=2321.350, \mathrm{df}=91$, Sig. $=0.000$; revisit intention $\mathrm{KMO}=0.849, \chi^{2}=1536.605$, $\mathrm{df}=6$, Sig.
$=0.000 . \mathrm{KMO}$ values of all scales were greater than 0.8 , reaching the Butler significance test level of sphericity, and the scale construction validity was good.

\subsection{Regression analysis}

In this paper, after standardizing the data of independent variables, moderators and dependent variables, the hypothesis was verified through hierarchical regression, as shown in Table 2. In Model 1, pull motivation was used as the independent variable and revisit intention was used as the dependent variable for regression. The standardized coefficient was 0.633 and the $\mathrm{R}^{2}$ change was 0.401 , both reaching the significance test level of 0.001 , indicating that pull motivation had a significant 
positive effect on revisit intention and had a strong predictive effect, supporting Hypothesis 1. In Model 2, based on Model 1, push motivation (potential moderating variable) was added into the independent variable, and the $\mathrm{R}^{2}$ change was 0.001 , which showed no significant increase. On the basis of Model 2, Model 3 added the interaction term of push and pull motivation to the independent variable. At this time, the $\mathrm{R}^{2}$ change was 0.022, which showed a significant increase. The adjustment effect of push motivation was significant, which supported Hypothesis 2. The standardized coefficient of the interaction term of push and pull motivation shows that push motivation negatively moderates the relationship between pull motivation and revisit intention, that is, the predictive effect of pull motivation on revisit intention weakens with the increase of push motivation, as shown in Figure 2.

Table 2. Hierarchical regression results

\begin{tabular}{|c|c|c|c|c|c|c|c|}
\hline Model & Variable & $\begin{array}{c}\text { Standardization } \\
\text { factor }\end{array}$ & T value & P value & R2 change & F change & $\begin{array}{c}\text { Significance of } \\
\text { F change }\end{array}$ \\
\hline 1 & Pull motivation & 0.633 & 15.613 & 0.000 & 0.401 & 243.757 & 0.000 \\
\hline 2 & Pull motivation & 0.650 & 12.953 & 0.000 & 0.001 & 0.325 & 0.569 \\
\hline & Push motivation & -0.029 & -0.570 & 0.569 & & & \\
\hline 3 & Push motivation & 0.594 & 11.506 & 0.000 & 0.022 & 13.846 & 0.000 \\
\hline & Push motivation & -0.072 & -1.420 & 0.156 & & & \\
\hline & $\begin{array}{c}\text { Pull motivation } \\
\text { *Push motivation }\end{array}$ & -0.173 & -3.721 & 0.000 & & & \\
\hline
\end{tabular}

Note: The dependent variable is intention to revisit.

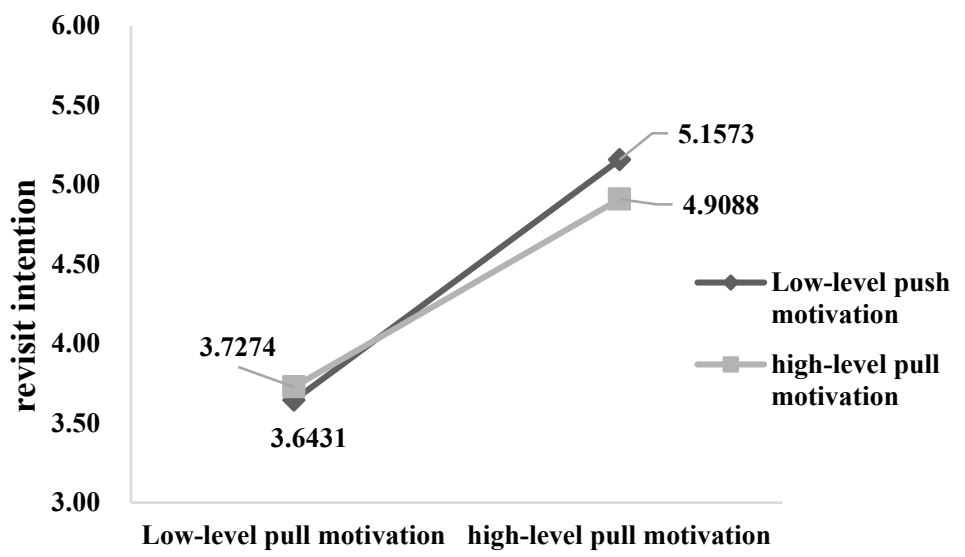

Figure 2. The moderating effect of motivation

\section{Conclusions}

Focusing on the field of health and wellness tourism, this paper studies the influence mechanism of pull motivation on revisit intention based on the new tourism motivation model. The research results are as follows :(1) pull motivation has a significant positive effect on revisit intention; (2) push motivation has a negative moderating effect on the relationship between pull motivation and revisit intention.

From the perspective of demand side, according to the push and pull theory, this paper identifies the push and pull motivation of health and wellness tourism, and studies the relationship between it and the intention to revisit. The research on tourism motivation is extended to the field of health and wellness tourism, and based on previous models, the moderating effect of push motivation between pull motivation and revisit intention is verified. In contrast, in this paper, the dependent variable is the revisit intention, suggests the moderating role of the push motivation not only exists between pull motivation and recommendation intention, also exists between pull motivation and revisit intention. This paper expands the application scope of this model, fills in the existing theoretical framework and empirical research gaps of health and wellness tourism to some extent, and provides a theoretical basis for the market segmentation and marketing of health and wellness tourism destination, as well as the improvement of tourists' revisit rate and the enhancement of sustainable development ability. Future research can be based on this model to verify the relationship between push and pull motivation and other variables in more research fields, and further test the applicability of this model.

\section{Acknowledgments}

This paper is one of the research results of "Research on Health Tourism Mode of Giant Panda National Park" (GJGY2019-ZC019), which is supported by National Park Research Center of Sichuan Social Science Key Research Base, and "Research on Optimal Path of Forest Health Products in Sichuan Province Based on 'Two Mountains' Theory" (201910626062), which is 
supported by Sichuan University Students' Innovation Training Program.

\section{References}

1. Yang X C, Song L Z, Zhong Y Y, et al.Study on spatial distribution characteristics and influencing factors of health tourism resources in Fujian Province [J]. Journal of Fujian Normal University (Natural Science), 2019, 35(5):106-116.

2. $\mathrm{Li} \mathrm{J} \mathrm{R}, \mathrm{Xu}$ D. Study on the construction of evaluation index system of forest health and tourism [J]. Forestry Economics, 2018(3):28-34.

3. Zhang $\mathrm{H}$ Q, Zhai X J, He Dan. Study on the innovative development of forest health care industry based on industrial integration: A case study of Heilongjiang Province [J]. Forestry Economics, 2019, 41(8):51-61.

4. Li Z W, Peng L M. Discussion on the Development of Forest Health Tourism Relying on National Forest Park -- Taking Zhejiang Yandang Mountain National Forest Park as an Example [J]. Forest Products Industry, 2017, 44(11):56-59.

5. Page S J, Hartwell H, Johns N, et al. Case study: Wellness, tourism and small business development in a UK coastal resort: Public engagement in practice[J]. Tourism Management, 2017, 60:466477.

6. Li P, Zhao Y M, Ye H Y. Analysis of Concepts Related to Health Tourism and International Research Progress [J]. Tourism Forum, 2020,13(1):69-81.

7. Dann G M S. Anomie, ego-enhancement and tourism[J]. Annals of Tourism Research, 1977, 4(4):184-194.

8. Wang J W, Yang J X, Zheng C H, et al.Study on the impact of tourists' motivation on destination image of black tourism destination -- A case study of Beichuan Earthquake Site [J]. Tourism Journal, 2019, 34(9):114-126.

9. $\mathrm{Xu} \mathrm{J}$, Chan $\mathrm{S}$. A new nature-based tourism motivation model: Testing the moderating effects of the push motivation[J]. Tourism Management Perspectives, 2016, 18:107-110.

10. Ryu E, Hyun S S, Shim C. Creating New Relationships Through Tourism: A Qualitative Analysis of Tourist Motivations of Older Individuals in Japan[J]. Journal of Travel \& Tourism Marketing, 2015, 32(4):325-338.

11. Jin X, Xiang Y, Weber K, et al. Motivation and involvement in adventure tourism activities: a Chinese tourists' perspective[J]. Asia Pacific Journal of Tourism Research, 2019, 24(11):1066-1078.

12. Luo J N, Zhao Y F. Research on China's Religious Cultural Tourism Market Segment Based on Tourism Motivation [J]. Journal of Management, 2015,12(8):1118-1123.
13. Wang J W, Zhang S I. Black Tourists at Disaster Memorial Sites: Motivation, Types and Differences -- A Case Study of Beichuan Earthquake Site. Geographical Research, 2016, 35(8):1576-1588.

14. Tahir A, Meltem C, Carl C. Mass tourism underwater: a segmentation approach to motivations of scuba diving holiday tourists[J]. Tourism Geographies, 2019,36(2):268-281.

15. Liu F J, Xu J Y, Wu N. Research on Factors Influencing Tourists' Intention to Re-visit Based on Meta-analysis [J]. Tourism Science,2019,33(1):3353.

16. Zhao X X, Luo P C. The Influence of Tourism Motivation of Rural Tourism Destinations on Revisit Intentions: The Mediating Role of Communication Intentions [J]. Journal of Fujian Normal University (Natural Science Edition),2019,35(06):108-116.

17. Ashton A S. Spiritual retreat tourism development in the Asia Pacific region: investigating the impact of tourist satisfaction and intention to revisit: a Chiang Mai, Thailand case study[J]. Asia Pacific Journal of Tourism Research, 2018, 23(11):1098-1114.

18. Beckman E, Whaley J E, Kim Y K. Motivations and Experiences of Whitewater Rafting Tourists on the Ocoee River, USA[J]. International Journal of Tourism Research, 2017, 19(2):257-267.

19. Klenosky, D B.The "pull" of tourism destinations: A means-end investigation [J].Journal of Travel Research.2002, 40(4):385-395. 